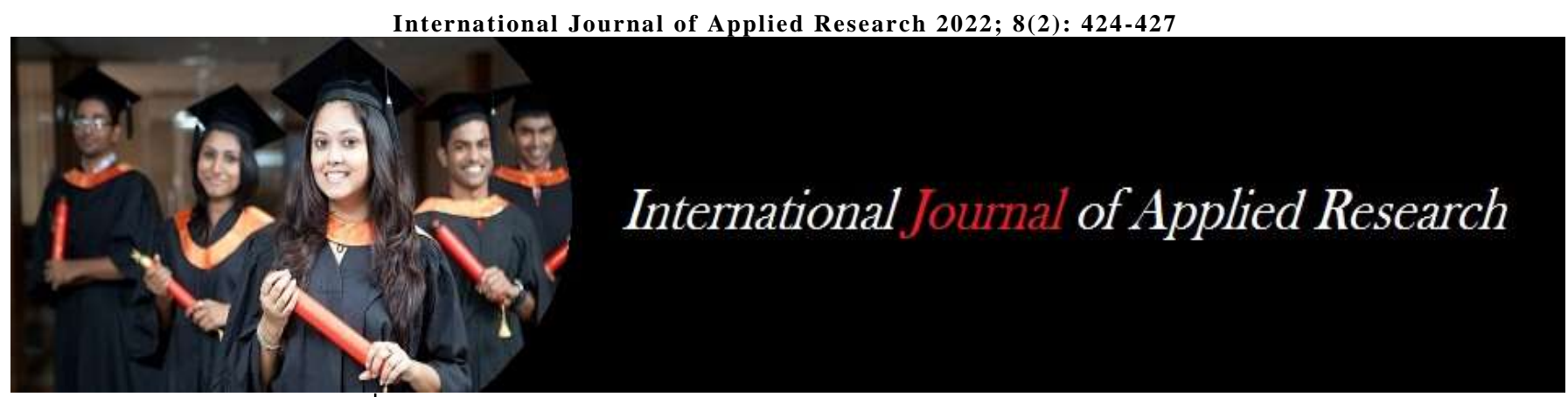

ISSN Print: 2394-7500

ISSN Online: 2394-5869

Impact Factor: 8.4

IJAR 2022; 8(2): 424-427

www.allresearchjournal.com

Received: 17-12-2021

Accepted: 20-01-2022

Anshula Dua

Junior Research Fellow

Faculty of Education, Dayal

Bagh Educational Institute,

Agra, Uttar Pradesh, India
Corresponding Author:

Anshula Dua

Junior Research Fellow

Faculty of Education, Dayal

Bagh Educational Institute,

Agra, Uttar Pradesh, India

\section{Evolution of steam and its implications}

\section{Anshula Dua}

DOI: https://doi.org/10.22271/allresearch.2022.v8.i2f.9479

\section{Abstract}

Approaches, methods and techniques are adopted by educators for imparting knowledge in every field whether its science, art, mathematics. The approaches meant for teaching are used so as to update the learners with the latest knowledge and help them overcoming the challenges faced in everyday life. It is said that scholarly approaches are adopted especially in science and technology. Such as the evolution of STEM approach which has led to STEAM and STREAM approach. Different developing and developed nations are trying to adopt and excel in the UNESCO's educational benchmark. Though there are limitation in resources, expertise and knowledge in context to emerging trends. STEAM is an educational model with the motto of how the traditional academic subjects can structured into a particular set framework which will help to plan integrated curriculum. It comprises of epistemologies of general as well as discipline related development in relation to individual discipline standards. When the researcher investigates such relationships so as to find out what is common. It is the need of the hour that different discipline work with one another in such a way that their combination is adorable that can work up in the different directions. This paper is an overview about the development of STEAM approach and its implications.

Keywords: Approaches, methods, techniques, stem, steam, stream

\section{Introduction}

As the evolution of man is a complex process and have various challenges at his/her existence. In context of science, various structures are used in order to solve the puzzle which aims at solving human life problems. According to Abimbola \& Omosewo (2006) [1], science is said to be as a body of knowledge and way of thinking in pursuit of understanding. Science is based on observation and experiment. Science is said to be as a subject whose nature is fact based and is learned through observation and experiment. Science education is said to be as learning science by adopting the process that is acquiring and developing theoretical knowledge via problem solving technique and scientific inquiry (Obeka, 2011) [10]. The result which are drawn from observation and experiment are presented as laws and principles. We can see the application of scientific facts is different field of arts, engineering, robotics and technology.

Technology is said to be the application of science in engineering, industry and beyond for the purpose of inventing machinery and equipment's which are helpful in solving problems. On the other hand engineering is said to be as the application of science and mathematics due to which energy are transfer for solving human problem. Engineering can also be seen as a work where there is designing and creation of different product by use of methods related to science. Mathematics can be separated from science as it includes algebra, calculus, geometry etc. it is also concerned with the study of different shape, number and quantity.

According to Sanders (2009) ${ }^{[12]}$, NSF that is National Science Foundation gave the term SMET which stands for Science, Mathematics, Engineering and Technology which was lately named as STEM that means for Science, Technology, Engineering and Mathematics, eventually STEM was used in business but after the significant results it was evolved as STEM education outside the classroom.

Lately STEM application was seen in the different field such as engineering, which led to manufacturing of different machines. The aim of STEM approach was to develop critical thinking skill that will eventually promote creative problem solving skills. 
The perception of researchers on STEM education indicates that students will get more benefit even if they refuse to pursue a post-secondary education and they will get more benefit if they attend college particularly in STEM related field (Butz et al., 2004) ${ }^{[3]}$. Before the invention of STEM, Thomas Edison and Henry Ford were slightly educated in some of apprenticeship. These two inventors produced technologies in history with the help of applying STEM principles. According to White (2014) ${ }^{[16]}$, STEM is said to be as the result of various historical event that were held before 1862. The Morrill Act, 1862 is said to be responsible of land grant universities after which the focus was on agricultural training and lately on engineering training program (Butz et al., 2004) ${ }^{[3]}$.

\section{Stem To Steam Education}

Earlier STEM education was referred as Science, Technology and Society (STS). It was emerged for updating the knowledge of the students and train their mind in the respective discipline so as to fulfil the needs of the society and to transform the human thinking skills into improving living.

It can be observed that STEM existed earlier or prior to classroom teaching while the application of STEM can be seen before approaches of learning. In the present scenario, it can be seen that the disciplines which are affiliated are now being studied from elementary level to higher education level. It can be said that STEM education still remain a challenge for developing country.

Science and mathematics is said as the foundation of STEM education. It is said that science and mathematics are the most recognised field in our academic field. On the other hand technology and engineering are under presented and underfunded in the field of education (White, 2014) ${ }^{[16]}$.

When we consider education as a transdisciplinary approach, STEM is said to be the old approach while in case of knowledge integration it serves the learners to enrich themselves and make meaning of the world. According to Adeyemo (2010) ${ }^{[2]}$, STEM is not only a challenge for students but also for the teachers who are working in developing country as it creates hindrances. Further, the efforts are being made by Korean government in which they are trying to integrate science with other disciplines through STEM education (Korea Ministry of Education, 2015).

STEAM education stands for Science, Technology, Engineering, Arts and Mathematics. Here arts comprises of expressiveness, developing understanding, emotional development and stimulating imagination that will lead to open-mindfulness. Further, emotional awareness is also developed. According to Eisner (2008), with the help of arts, students are able to discover nature and humanity. As per different scholars, STEAM education is said to be the combination of science and arts so as to produce a workforce which is as per the $21^{\text {st }}$ century that is creative, ethical and scientifically literate (Feldman, 2015; Piro, 2010) ${ }^{[6,11]}$. Various countries like China, Korea and US have already begun the production of STEAM curriculum (White, 2010) [17]. It has been observed that science educators have found that there is limitation of higher-order abilities among the students which has led them to team up with colleagues in the field of arts so as to design innovative as well as interdisciplinary STEAM curriculum and teaching approaches (Sousa \& Pilicki, 2013) ${ }^{[14]}$.
The transformation which is from STEM to STEAM was a movement for educators and researchers. For the positive mode of education, arts was added in STEM education for the $21^{\text {st }}$ century. There was a paradigm shift when arts was added for the purpose of conscious use of creative imagination which will lead to development of aesthetic objects along with design of solving problem. As per employers and educators STEM missed certain aspects which were vital for students so as to grow their career in future. In case of STEAM approach, it involves learning through the application of science, technology, engineering, arts and mathematics as it will guide them towards problem solving, critical thinking and inquiry. According to Taylor (2016) ${ }^{[15]}$, students who are ready to take the risk are engaged in experimental learning, embracing collaboration and are working through the creative process. STEAM approach have introduced different dimensions about how STEM education is being used in the classroom. With the introduction of arts in STEM we can see diversity into the package. With the help of STEAM, students can make vital use of the opportunity where they can relate their learning experiences in the different areas along with arts standards and design. According to Taylor (2016) ${ }^{[15]}$, STEAM has replaced its predecessor in terms of innovation and inquiry. It has been observed that STEAM education has provided benefits by engaging minority and disadvantaged students which has resulted into improving numeracy competencies and literacy (Clark, 2014; Stoelinga, Silk, Reddy \& Rahman, 2015) ${ }^{[4,13]}$. According to Holm (2011) ${ }^{[7]}$, STEAM curriculum empowers science teachers to get themselves engaged in school based curriculum development. With the help of STEAM education, students can transform their own learning, that is based on five ways of knowing and that are: - experiential knowing, relational knowing, visionary \& ethical knowing, critical knowing and self-knowing (Taylor, 2016) ${ }^{[15]}$.

\section{Why Steam Is Important?}

\section{S T

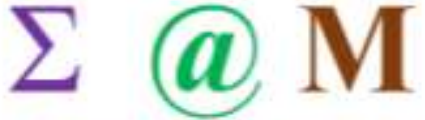 \\ Science Technology Engineering Arts Mathematics}

As the economy and job market is changing but in contrary our education hasn't changed as per it. It becomes vital, for student to learn the subject area in their classroom setting. Mission of STEAM is to enhance two aspects of teachinglearning and that are how teachers teach and how to facilitate students in developing the skills that will be helpful for their own future. Students need to enter the workplace with a set of various skills which allow them to evolve and adapt themselves as per the change in present scenario. STEAM comprises of five major disciplines together so as to create an environment that motivates students to participate and collaborate. According to National Educational Association, mainly there are four skills necessary in $21^{\text {st }}$ century:

- Creativity and innovation

- Collaboration

- Communication

- Critical thinking and problem solving 
As new strategies are being explored so that students becomes innovator and creators, STEAM is being emphasised as an avenue so as to make this happen.
STEAM is said to be as an experiential form of learning which aims at building skills of children and developing concept understanding. Here is how STEAM education is used:-

\section{Implications of steam education}

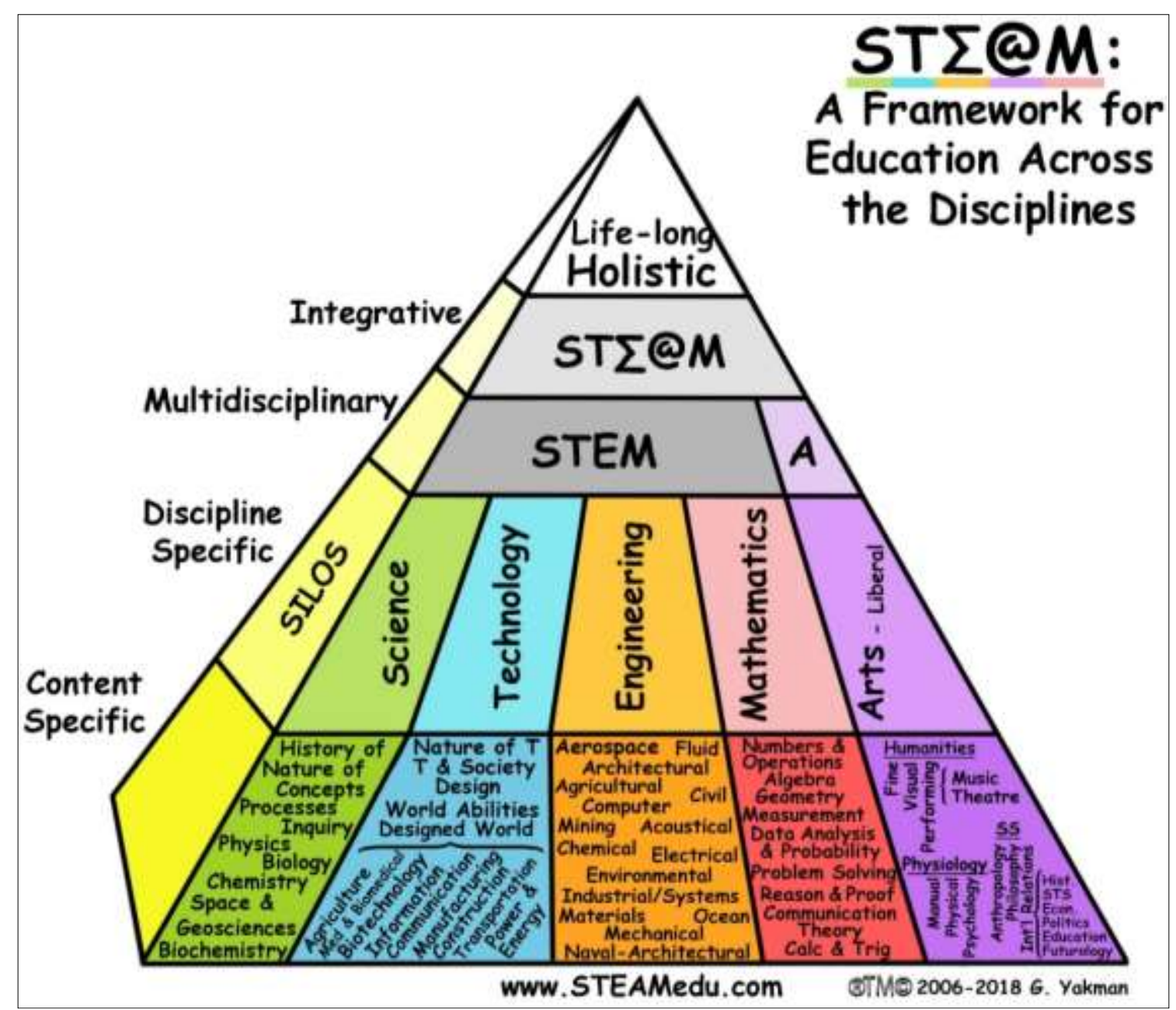

Source: Manager, S. (2019) ${ }^{[9]}$. STEAM Pyramid History. STEAM Education. https://steamedu.com/pyramidhistory/

Fig 1: STEAM: A Framework for Education across the Disciplines

\section{Integrated level}

The second level of the pyramid is the integrated level. At this level students will obtain a broad scope of all the fields.

\section{Multidisciplinary level}

In multidisciplinary level, students will be able to obtain a scope of specifically chosen fields and will also be able to get overview of how they inter-relate in reality.

\section{Discipline specific level}

At this level individuals are taught as per divisions of fields or disciplines.

\section{Content specific level}

At this level specific content areas are studied in detail. It helps the students in their professional development.

\section{Other Implications}

1. Focus on skill- based education

On one hand STEAM education builds skills while on the other hand it gives challenges as well. Students are learning how they can build things which they will be able to relate in their real life. STEAM comprises of life skills such as problem solving, communication, collaboration and critical thinking which helps in the overall development of the child.

\section{Interdisciplinary and trans-disciplinary}

STEAM methodologies can be integrated with Indian board. In inter-disciplinary model a subject is integrated with a topic and outcomes while in trans-disciplinary approach any curriculum can be created across the programme.

\section{Teachers vs Educators}

Educators are the architect of experiential learning in classroom. Educators work together with the students so as to enable them in learning rather than becoming the source of knowledge. Educators try to develop different skills among the students such as critical thinking. Unlike teachers, educators are moving from traditional approach to informal and creative learning environment.

\section{Innovative parameters of evaluation}

By adopting STEAM education, parameter becomes transparent and helps child in self-discovery. STEAM approach enables learner to find out solution which has 
tangible outcomes. Innovation in technology such as robotics and artificial intelligence are useful for children as now they can learn from their own innovations rather than following a set of instructions.

\section{Conclusion}

STEAM education enriches and expands the scope of STEM education. It is a curriculum philosophy which focuses on empowering science teachers so as to engage in schoolbased curriculum development. It also involves teachers in developing a humanistic vision for the $21^{\text {st }}$ century education and their role as professional educators. It provides a creative design space for teachers in various learning areas for the purpose of collaborating and developing integrated curriculum. Innovative teacher can design and implement STEAM education on a modest scale. According to Taylor (2016) ${ }^{[15]}$, STEAM educations leads to engage students in transformative learning, which is based on five interconnected ways of knowing that are: cultural self- knowing, relational knowing, critical knowing, visionary and ethical knowing, knowing in action.

\section{References}

1. Abimbola IO, Omosewo EO. History of science for degree students. Ilorin: Oyinwola Press. 2006.

2. Adeyemo SA. Teaching \& Learning of Physics in Nigerian Secondary Schools: The Curriculum Transformation, Issues, Problems and Prospects. International Journal of Educational Research and Technology. 2010;1(4):99-111.

3. Butz WP, Kelly TK, Adamson DM, Bloom GA, Fossum D, Gross ME. Will the scientific and technology workforce meet the requirements of the federal government? Pittsburgh, PA: RAND. 2004.

4. Clark AR. Boston Arts Academy: Teaching and learning reports. 2014, 2013-2014. http://bostonartsacademy.org/site/wpcontent/uploads/20 12/08/2013_14_TeachingandLearningReports.pdf

5. Eisner E. Art and knowledge. In J. G. Knowles \& A. L. Cole (Eds.). Handbook of the arts in qualitative research. Thousand Oaks, California: Sage. 2008.

6. Feldman A. STEAM rising: Why we need to put the arts into STEM education. 2015. http://www.slate.com/articles/technology/future_tense/2 015/06/steam_vs_stem_why_we_need_to_put_the_arts _into_stem_education.html

7. Holm M. Project-based instruction: A review of the literature on effectiveness in prekindergarten through 12th grade classrooms. Rivier Academic Journal. 2011;7(2):1-13. http://bie.org/object/document/projectbasedlear

8. Korea Ministry of Education. 2015 개정 과학과 교육과정 [The 2015 Revised Science Curriculum]. Report no. 2015, 2015-74. Sejong: Author.

9. Manager S. STEAM Pyramid History. STEAM Education. 2019. https://steamedu.com/pyramidhistory/

10. Obeka SS. Environmental Education Reform on Solid Waste Management in Nigeria: The Case of Zaria Municipal of Kaduna State. STAN 52 $2^{\text {nd }}$ Annual Conference. HEBN Publishers Plc. 2011.

11. Piro J. Going from STEM to STEAM: The Arts have a role in America's future too. Education Week. 2010;29(24):28-29. http://www.edweek.org/ew/articles/2010/03/10/24piro.h 29.html?qs=STEAM

12. Sanders M. STEM, STEM education, STE Mmania. The Technology Teacher. 2009;68(4):20-26.

13. Stoelinga SR, Silk Y, Reddy P, Rahman N. Final evaluation report: Turnaround arts initiative. Washington, DC: President's Committee on the Arts and the Humanities. 2015. http://pcah.gov

14. Sousa DA, Pilecki T. From STEM to STEAM: Using brain-compatible strategies to integrate the arts. Thousand Oaks, California: Corwin/Sage. 2013.

15. Taylor PC. Transformative science education. In R. Gunstone (Ed.). Encyclopedia of Science Education Dordrecht, The Netherlands: Springer. 2016, 10791082.

16. White DW. What is STEM education and why is it important? Florida Association of Teacher Educators Journal. 2014;1(14):1-9. http://www.fate1.org/journals/2014/white.pdf

17. White HP. STEAM not STEM whitepaper: An agreement on what drives the US economy in the future. 2010. http://steam-notstem.com 